\title{
A psychological intervention proposal on coping with pain for children with Sickle Cell Disease
}

\author{
Uma proposta de intervenção psicológica no coping da dor em crianças \\ com Anemia Falciforme
}

\author{
Christyne Gomes Toledo de OLIVEIRA ${ }^{1}$ \\ Sônia Regina Fiorim ENUMO2,3 \\ Kely Maria Pereira de PAULA ${ }^{4}$
}

\begin{abstract}
Pain is common in Sickle Cell Disease. This study proposes a Psychological Intervention Program for Children with Sickle Cell Disease (Intervenção Psicológica para Crianças com Anemia Falciforme). It was applied to seven children in a hospital. The intervention was based in the Motivational Theory of Coping and includes the Coping with Pain Game (Jogo "Enfrentando a Dor"). The Computerized Assessment Instrument of Coping with Hospitalization-Pain (Instrumento Computadorizado para Avaliação do Enfrentamento da Hospitalização-Dor) was applied before and after seven weekly sessions. The results showed significant increase in the facilitating behaviors to cope with pain, and in problem-solving, an adaptive coping; and a reduction in the non-facilitating behaviors and in rumination, a maladaptive coping. The stressor perception as a challenge to the need of competence increased, whereas the stressor perception as a threat to the need of competence and autonomy decreased. This intervention may have contributed to promote adaptive coping with pain.
\end{abstract}

Keywords: Anemia, sickle cell; Children; Coping; Pain; Psychological intervention.

\section{Resumo}

A dor é comum na Anemia Falciforme. Este estudo propôs um Programa de Intervenção Psicológica para Crianças com Anemia Falciforme, aplicado em sete crianças, em um hospital. A Teoria Motivacional do Coping baseou a intervenção que incluiu o Jogo "Enfrentando a Dor". Antes e após sete sessões semanais, foi aplicado o Instrumento Computadorizado para Avaliação do Enfrentamento da Hospitalização-Dor. Os resultados mostraram um aumento significativo dos

${ }^{1}$ Centro Universitário Católico de Vitória, Curso de Psicologia. Av. Vitória, 950, Forte São João, 29017-950, Vitória, ES, Brasil. Correspondência para/Correspondence to: C.G.T. OLIVEIRA. E-mail: <cgtoliveira@gmail.com>.

2 Pontifícia Universidade Católica de Campinas, Centro de Ciências da Vida, Programa de Pós-Graduação em Ciências da Saúde. Campinas, SP, Brasil.

${ }^{3}$ Pontifícia Universidade Católica de Campinas, Centro de Ciências da Vida, Programa de Pós-Graduação em Psicologia. Campinas, SP, Brasil.

${ }^{4}$ Universidade Federal do Espírito Santo, Centro de Ciências Humanas e Naturais, Programa de Pós-Graduação em Psicologia. Vitória, ES, Brasil

Support: C.G.T. OLIVEIRA was supported by the Coordenação de Aperfeiçoamento de Pessoal de Nivel Superior. S.R.F. ENUMO was funded by the Conselho Nacional de Desenvolvimento Científico e Tecnológico (Process n 481483/2009-8).

Article derived from the doctoral thesis of C.G.T. OLIVEIRA, entitled "Enfrentando a dor na Anemia Falciforme: uma proposta de avaliação e intervenção psicológica com crianças”. Universidade Federal do Espírito Santo, 2013.
} 
comportamentos facilitadores do coping da dor e da solução de problemas, uma estratégia adaptativa, e uma diminuição nos comportamentos não facilitadores e na ruminação, uma estratégia mal adaptativa. A percepção do estressor como desafio à necessidade de competência aumentou e diminuiu a percepção de ameaça às necessidades de competência e de autonomia. A intervenção pode ter contribuído para promover o enfrentamento adaptativo da dor.

Palavras-chave: Anemia falciforme; Crianças; Coping; Dor; Intervenção psicológica.

Sickle Cell Disease (SCD) is the most prevalent hereditary hemoglobinopathy in Brazil. It is estimated that 3,500 children are born with SCD every year, with prevalence of African descendent infants (Brasil, 2013). This disease is characterized by a genetic alteration in the hemoglobin $\mathrm{S}(\mathrm{Hb} \mathrm{S})$ that modifies the shape of red blood cell, changing it into a half-moon or sickle shape (Brasil, 2013). This change is responsible for the vaso-occlusive crisis or pain crisis, a common painful complication of the disease (Miranda \& Brito, 2016) and the main cause of hospitalization (Brasil, 2013; Sabino \& Gradella, 2016).

Many of these pain crises vary in intensity and can occur without an apparent prior event (Armstead \& D'Souza, 2011) or as consequence of stressful events: extremes of heat or cold; dehydration; and interpersonal and family conflicts (Batista, Camargo, \& Moraes, 2011). This variety of triggering factors and the high incidence of painful crises have increased the concern of specialists regarding the evaluation and appropriate pain management (Dias, Oliveira, Enumo, \& Paula, 2013) and the impact of symptoms on the quality of children's life (Menezes, Len, Hilário, Terreri, \& Braga, 2013).

To the Sickle Cell Disease pain management, a medication called Hydroxyurea ( $\mathrm{HU}$ ) has been widely used, and it is considered an important advance in this disease treatment (Brasil, 2013; Silva-Pinto et al., 2013). Non-pharmacological techniques for pain control have also been proven effective, such as distractions like watching television, chatting with friends, and playing video games or any other games, progressive muscle relaxation, deep breathing exercises, and supportive psychotherapy based on the principles
Chen, Cole, \& Kato, 2004; Dias et al., 2013; Miranda \& Brito, 2016).

The use of games in psychological interventions with children has produced positive results regarding the disease (Chen et al., 2004; Moura, Costa Junior, Dantas, Araújo, \& Collet, 2014; Mussa \& Malerbi, 2008). Motta and Enumo (2010) carried out a study on hospitalized children with cancer and showed the effect of a psychological intervention based on problemcentered playful activities and ways of coping with hospitalization to promote children's behavioral repertoire aiming at reducing the emotional effects of this condition.

From a developmental perspective, coping and self-regulation are closely related processes that allow a broad understanding of the influence of stressors on infant development (Skinner \& Wellborn, 1994). Coping is defined as how people adapt to stressful situations by regulating behavior, emotion, and motivational orientation seeking to maintain, restore, or repair the fulfillment of the basic psychological needs of competence, autonomy, and relatedness (Skinner, Edge, Altman, \& Sherwood, 2003; Skinner \& Wellborn, 1994).

According to the Motivational Theory of Coping (MTC), the coping process is understood as a structural and hierarchical system (levels). Before a stressful event, people can present several instances of coping at the basis of structure, and ways of coping; functional categories of coping instances that are functionally related. They are attempts to maintain, restore or repair the basic needs of relatedness, autonomy and competence. When a stressor is realized as a challenge, the adaptive responses are classified into six high-order categories (coping family or macro-categories), as follows: Self-comforting or Self-confidence, 
and Support Seeking concerning the need of Relatedness; Problem-solving and Information Seeking need of Competence; and Accommodation and Negotiation, need of Autonomy. In contrast, realized threat may lead to maladaptive responses related to six other families: Delegation and Social Isolation (Relatedness); Helplessness and Escape (Competence); and Submission and Opposition (Autonomy) (Ramos, Enumo, \& Paula, 2015; Skinner et al., 2003; Skinner \& Wellborn, 1994; Skinner \& Zimmer-Gembeck, 2016; Vasconcelos \& Nascimento, 2016)

Studies have been conducted aiming at investigating how children cope and adapt to adverse situations aiming to assess pain and coping of SCD children and their relationship with health service utilization, Anie, Steptoe, Dick, and Smalling (2002) found that children high on passive adherence had higher pain perception intensity, and those who showed more active coping sought for health services more often. The authors concluded that children may benefit from interventions that incorporate both medical and psychological strategies to manage SCD pain.

In Brazil, Garioli (2011) studied coping with SCD of 12 children aged 8 to 10 years old using the Computerized Assessment Instrument of Coping with Hospitalization-Pain (AEH-DOR, Instrumento Computadorizado para Avaliação do Enfrentamento da Hospitalização-Dor). The most usual ways of coping were rumination, problemsolving, and cognitive restructuring. These last two ways of coping are adaptive, but high-frequency of rumination makes children vulnerable to the development of internalized problems due to the focus on the negative aspects of the disease (Hostert, Motta, \& Enumo, 2015; Lima, Barros, \& Enumo, 2014; Motta \& Enumo, 2010; Motta et al., 2015; Skinner \& Zimmer-Gembeck, 2016).

Other studies have highlighted as interventions focused on ways of coping make up measures to protect children's development (Anie, 2005; Carnier, Padovani, Perosa, \& Rodrigues, 2015; Compas, Jaser, Dunn, \& Rodriguez, 2012;
Lima et al., 2014; Motta \& Enumo, 2010). Despite the relevance of studying on coping with chronic diseases and the damages of SCD on child development, there are not many studies focusing on psychosocial interventions in this population in Brazil. Therefore, the present study presents the Psychological Intervention Program for Children with Sickle Cell Disease (PIPCAF, Intervenção Psicológica para Crianças com Anemia Falciforme), which is focused on the process of coping with pain based on the Motivational Theory of Coping.

\section{Method}

\section{Participants}

The single-subject research design, in which the subject serves as his/her own control, was used in the present study with pre-test/intervention/ post-test. The sample was composed by seven children - four boys - aged 8 to 10 years old with SCD (International Classification of Diseases ICD10: D57.0) who were receiving treatment in the pediatric hematology outpatient clinic in the Hospital Universitário "Cassiano Antônio Moraes", at the Universidade Federal do Espírito Santo (UFES), in Vitória, Espírito Santo State, Brazil. This hospital is a reference in SCD treatment.

The children were elementary school students attending 2 nd- 5 th grades. A child was only held back a grade because of frequent absences due to disease complications. Pain frequency data since the beginning of the outpatient ward monitoring onwards indicated a total of 34 pain episodes without hospitalization $(M=4.9, S D=$ 2.0) and total frequency of 49 hospitalizations $(M=7.0 ; S D=4.9, M d=6$, variance $=3$ to 17 episodes). For 6 children, the treatment included the use of Hydroxyurea for about 12 months. The decrease in the frequency of hospitalizations after the use of this medication was observed among all children, although pain had remained to some 
degree for at least two episodes.

The selection criteria included: (a) diagnosis of SCD, hemoglobin SS, considered in the medical literature as the most severe sort of disease (Brasil, 2013); (b) report of at least one pain episode the past six months to ensure retrospective of pain reports; and (c) children aged between 8 to 10 years and 11 months old due to adequate verbal repertoire to provide information about the disease condition and understand the proposed activities. Children with any motor or cognitive impairment were not selected to participate in this study. The children who were experiencing persistent and intense pain, measured by a visual analog scale, did not participate in the PIPCAF intervention program even if they were taking pain medication.

The present study was approved by the Research Ethics Committee of the UFES (Process $n^{\circ}$ 128/11), according to Resolution $n^{\circ} 466 / 2012$ of the Conselho Nacional de Saúde do Ministério da Saúde do Brasil (National Council of Health of the Ministry of Health in Brazil). The hospital's board of directors granted authorization, the children's parents or legal guardians signed the Informed Consent Form, and the children signed the Assent Form. The pre-test and post-test were developed at the Pediatric Clinic of the hospital, and the intervention was administered at the Applied Psychology Center of the UFES.

\section{Instruments}

A protocol was used to collect the medical records of each child, with information about the disease; history, symptoms, and treatment, and the socio-demographic data on the children and their family.

To evaluate the perceived pain in the child before and after the execution of all stages of the research, the Faces Pain Scale - Revised (FPS-R) was applied (Hicks, von Baeyer, Spafford, van Korlaar, \& Goodenough, 2001; Poveda, Silva, Passareli, Santos, \& Linhares, n.d.). It consists of six cartoons illustrating facial expressions and a numerical rating scale ranging from 0 - no pain to 10 - extremely intense pain.

To make up the PIPCAF and analyze its effects on the post-test, the AEH-DOR, adapted from the AEHcomp - Instrument of Coping with Hospitalization (Instrumento Computadorizado para Avaliação do Enfrentamento da Hospitalização) (Motta \& Enumo, 2010) was used. It consists of versions for boys and girls of 20 colored pictures with questions about the children's response. The drawings picture situations to identify what children do, think, and feel when they experience pain, representing instances of coping or "coping behaviors", such as playing, crying, and feeling anger, among others, which is answered on a five-point Likert scale ranging from never to always. After the child's response, we ask, for example, on the "Playing" picture: "Why have you/have you not played to face the pain?" Upon analysis of the children's responses, it was possible to identify 14 ways of coping, which are frequently found in studies with children with chronic diseases (Lima et al., 2014; Motta \& Enumo, 2010) and are related to MTC's 12 families of coping.

Amongst the 14 ways of the identified coping, there were eight that were adaptive to coping with pain: distraction, acceptance, problem-solving, comfort seeking, emotional regulation, negotiation, information seeking, and cognitive restructuring, and six are maladaptive; rumination, avoidance, helplessness, complaints, social withdrawal, and blaming others. For each picture, the child can indicate more than one justification, then several ways of coping can be reported.

\section{Procedures}

The present study was carried out in four phases: identification of the participants and collection of clinical data from their medical records; application of AEH-DOR (pre-test); development and application of PIPCAF; and application of AEH-DOR (post-test).

The AEH-DOR was applied individually by the researcher, with the assistance of a Master's 
degree student (Coordenação de Aperfeiçoamento de Pessoal de Nivel Superior scholarship), with an average duration of $30 \mathrm{~min}$ (pre-test) and $21 \mathrm{~min}$ (post-test). The intervention was carried out in small groups by the first author with the assistance of a psychologist, with an average duration of 90 minutes per session; it was recorded for later analysis.

For each child's response to each AEH-DOR picture, a score was assigned (from no $=0$ to always $=4$ ) obtaining the total score. Afterwards, behaviors perceived as facilitating ('improvement') or nonfacilitating ('non-improvement') of coping with pain were analyzed. The average proportion of each one of these behaviors was then calculated. The children's justifications for each recorded response were transcribed and categorized, allowing the calculation of the average frequency of each one of the 14 ways of coping identified. The children's justification too allowed analyses of the adaptive process seen as a challenge or threat to the need of relatedness, competence, and autonomy. The average of the proportions was calculated.

To assess the reliability of the analyses, the Concordance Index (CI) of the classifications of the ways of coping and justifications in the AEH-DOR was calculated by three judges (two of them were doctorate students) for all responses. This calculation was done between pairs of observers $(A B, B C$, and $A C)$, accepting a minimum value of $70 \%$, considered sufficient to determine the reliability of the pre-test and post-test scores.

To analyze the changes related to the PIPCAF (changes in the pain coping repertoire and the adaptive process), the Wilcoxon test ( $p \leq 0.01$; $p \leq$ $0.05)$ was used in the AEH-DOR pre-test and posttest. To assess the changes in the coping process, the clinical significance was calculated based on the rate gain (post-test score minus pre-test score multiplied by 100 minus 100). The AEH-DOR is not a standardized instrument; therefore, the rate gain was calculated using the criteria of an improvement of at least 30\% to be considered clinically significant (McGlinchey, Atkins, \& Jacobson, 2002).

\section{Results}

The PIPCAF was based on the analysis of coping with pain related to SCD and the AEHDOR in the pre-test aimed at: (a) expanding the behavioral repertoire for prevention and controlling of pain; (b) the maintenance and promotion of adaptive ways of coping with pain; (c) decreasing the maladaptive ways of coping, i.e., those that are risky to maladaptive results of painful crisis; (d) promoting the perception of stressors more as a challenge and less as a threat to the three basic psychological needs.

Based on this analysis, the PIPCAF was administered in four stages divided into seven semi-structured sessions in group:

Stage 1 - Integration (2 sessions): aims to promote integration between the children using group dynamic techniques to introduce the participants and establish the rapport, the trust and the therapeutic contract.

Stage 2 - Identification and expression of feelings ( 2 sessions): to promote the expression and development of self-observation skills and identification of feelings and thoughts regarding pain and the disease. At this stage, techniques, such as "Facial expression recognition", "Progressive muscle relaxation", "My badge of courage", and "Coping cards", adapted from Friedberg and McClure (2008), are used. At the end of this stage, the children receive the Pain Diary to make notes about their feelings, pain management techniques used, relevant situations during the week, and the feelings in those situations. Every child who submits the completed notebook, the diary, gets "heart" and "courage" tokens, which are used during the Coping with Pain Game (JEDOR, Jogo Enfrentando a Dor), a psychotherapeutic board game specially elaborated for this study.

Stage 3 - Coping with Pain Game (JEDOR) (2 sessions): aims to help the child identify, reflect, and analyze everyday situations that can cause fear, suffering, stress and precipitate or increase painful sensation, as well as teach them strategies 
for dealing with these situations. This board game includes techniques such as distraction, information seeking, social support training strategies, and problem-solving and social skills development to respond to several challenges, focusing on the pain, the disease, and everyday situations.

The JEDOR was applied in two sessions of $1 \mathrm{~h} 20 \mathrm{~min}$ each. It includes an instruction manual, a dice, 4 colorful pieces shaped as cars, a close circuit board with colored spaces (white, yellow, blue, orange, and red), 13 neutral cards (yellow spaces), 14 coping cards (blue spaces), 10 dilemma cards (orange spaces), 4 challenge cards (red spaces), cards named "courage" and "heart", and behavior and coping cards. Each card has a specific purpose. The neutral cards (yellow spaces) are used for training the manner of coping distraction and are composed of sentences focusing on amusing and enjoyable tasks. Example: Neutral card 1- "Imitate the sound of three musical instruments".

The coping cards (blue spaces) are designed to develop the 14 ways of coping. They are composed of a problem with an adaptive or maladaptive solution and a corresponding consequence, such as: Coping card 6 - "Today is your first day at a new school and you do not know anyone. You feel nervous and prefer to be alone during recess" (Lose 1 courage card) (way of coping: avoidance).

The dilemma cards (orange spaces) are aimed at exploring the 14 ways of coping and are composed of a problem with two previously formulated solutions adaptive and maladaptive. The child chooses which solution he/she would use in that situation, with a respective consequence. For example: Dilemma card 1 - "You are sitting in class and you need to go to the bathroom, what do you do, think, or feel?" (A) Nothing, and hold it to the end of class, because you are embarrassed to ask the teacher to leave the class (Move backward 1 space) (way of coping: helplessness); (B) You ask the teacher for permission and say you need to go to the bathroom (Move forward 1 space) (way of coping: problem-solving).
The challenge cards (red spaces) also target the training of the 14 ways of coping, and they are composed of problem situations. Example: Challenge card 1- "Vera's story" - ways of coping: problem-solving, rumination, social isolation, and helplessness. Challenge card 1 story: "Vera is 9 years old and she has recently moved to a new school. (...) she is feeling very lonely, ... Vera has thought about looking for her former schoolmates, but they live very far away and certainly would also have made new friends" (Z.A.P. Del Prette \& Del Prette, 2011, p.213). "How do you and your team think Vera could solve her problem?".

In the JEDOR, children find solutions to the challenges presented, and they can win or lose heart and courage tokens and gain coping and behavior cards, tailored according to the solutions to the challenges. These cards and tokens are counted at the end of the game to determine the winner (the one who has more tokens and cards).

Stage 4 - Closure and self-assessment (1 session): the objective is to discuss and evaluate the activities performed in the intervention and the child's satisfaction in participating, as well as to encourage the children to use techniques they have learned to prevent and manage painful crisis. At this stage, drawing techniques and free playing are used. Each group does the evaluation of their participation, and a Satisfaction Inventory is applied.

Along the PIPCAF, no child reported pain, according to FPS-R. During the session breaks, two children were hospitalized for pain control, one due to a stroke. The group presented facilitating behaviors to cope with pain, especially in the game sessions (Stage 3), demonstrating engagement in proactive behaviors, such as planning strategies, asking someone about pain, asking for help, changing feelings, cooperating, and distracting to deal with the challenges presented in the activities.

In one of the activities in Stage 2, which aimed at promoting self-observation and identification and expression of feelings and thoughts regarding pain and disease, there were reports indicating 
non-facilitating behaviors to cope with pain, such as "I do not like to talk about it when I feel pain". This finding demonstrates that when children experience pain or encounter situations that evoke it, they can show discouragement (way of coping: helplessness), isolation (way of coping: isolation), avoidance (way of coping: escape) and/ or focus on the negative aspects (way of coping: rumination). Similarly, there were reports indicating the need to change their way of thinking (way of coping: cognitive restructuring) to deal with pain, to do something (way of coping: problem-solving), and to accept or adapt to their condition (way of coping: acceptance).

The registers in the Pain Diary, during the two sessions of the JEDOR (Stage 3) indicated that two children had had pain. One child had back pain, intensity eight while playing tag for two hours with his brother. The pain stopped only after the child took medicine, and she reported sadness in the pain crisis. It was observed that the presence of high intensity pain, triggered by physical activity; running, although a pleasurable game, causes sadness, and it was necessary for a pharmacological management by medical guidance in this case (way of coping: problem-solving). Another child reported having moderate pain, even with the use of Hydroxyurea. She felt sadness due to this unpredictable nature of pain. She used non-pharmacological management techniques, such as massages performed by her mother (way of coping: comfort seeking) and relaxation (way of coping: problem-solving). It is important to highlight that this relaxation technique was used during intervention.

In the overall assessment of the group, the children reported having really enjoyed participating in the PIPCAF. When questioned about their preferred activity, they all referred to the JEDOR (Stage 3).

\section{Coping process analysis after the intervention}

Analyzing the average proportion of coping behaviors, it was observed that the average of the facilitating behaviors to cope with pain was higher than the non-facilitating, with statistically and clinically significant differences (Table 1).

The analysis of the average ways of coping with pain showed a significant increase in the average of the adaptive ways of coping, and a statistically and clinically significant decrease in the maladaptive one (Table 2).

Table 1

Pre-test and post-test average percentage and rate of gain of facilitating and non-facilitating behaviors to cope with pain in children with sickle cell disease $(N=7)$

\begin{tabular}{|c|c|c|c|c|c|}
\hline Pain coping behaviors & Phase & M & SD & ${ }^{*} p$-value & Rate of gain (\%) \\
\hline \multirow[t]{2}{*}{ Facilitating (\%) } & pre-test & 49.5 & 15.9 & \multirow{2}{*}{$0.043^{*}$} & \multirow{2}{*}{$31.92^{\mathbf{a}}$} \\
\hline & post-test & 66.0 & 07.7 & & \\
\hline \multirow[t]{2}{*}{ Non-facilitating $r(\%)$} & pre-test & 50.5 & 15.9 & \multirow{2}{*}{$0.043^{*}$} & \multirow{2}{*}{$-31.28^{a}$} \\
\hline & post-test & 34.0 & 07.7 & & \\
\hline
\end{tabular}

Note: ${ }^{*} p \leq 0.05$, Wilcoxon test; a Clinically significant: $\geq 30 \%$ in the post-test.

Table 2

Pre-test and post-test average percentage and rate of gain of ways of coping with pain in children with sickle cell disease $(n=7)$

\begin{tabular}{|c|c|c|c|c|c|}
\hline Ways of coping with pain & Phase & $M$ & SD & ${ }^{*} p$-value & Rate of gain (\%) \\
\hline \multirow[t]{2}{*}{ Adaptive (\%) } & pre-test & 72.3 & 13.9 & \multirow{2}{*}{$0.018 *$} & \multirow{2}{*}{20.88} \\
\hline & post-test & 88.7 & 5.3 & & \\
\hline \multirow[t]{2}{*}{ Maladaptive (\%) } & pre-test & 27.7 & 13.9 & \multirow{2}{*}{$0.018^{*}$} & \multirow{2}{*}{$-54.51^{a}$} \\
\hline & post-test & 11.3 & 5.3 & & \\
\hline
\end{tabular}

Note: ${ }^{*} p \leq 0.01$, Wilcoxon test; a Clinically significant $\geq 30 \%$ in the post-test. 
When we compared the average perception of the stressor as a threat or a challenge to the three basic needs, there was a significant increase in the average coping related to the challenge to Competence, and a significant decrease in the average of the threat to Competence and Autonomy. There was also a clinically significant decrease in the perception of the stressor as a threat to Relatedness and to Competence, and an increase in the perception of the stressor as a challenge to Competence (Table 3).

Table 3

Pre-test and post-test average percentage and rate of gain of perceived threat or challenge to the psychological basic needs - relatedness, competence, and autonomy - in children with sickle cell disease $(n=7)$

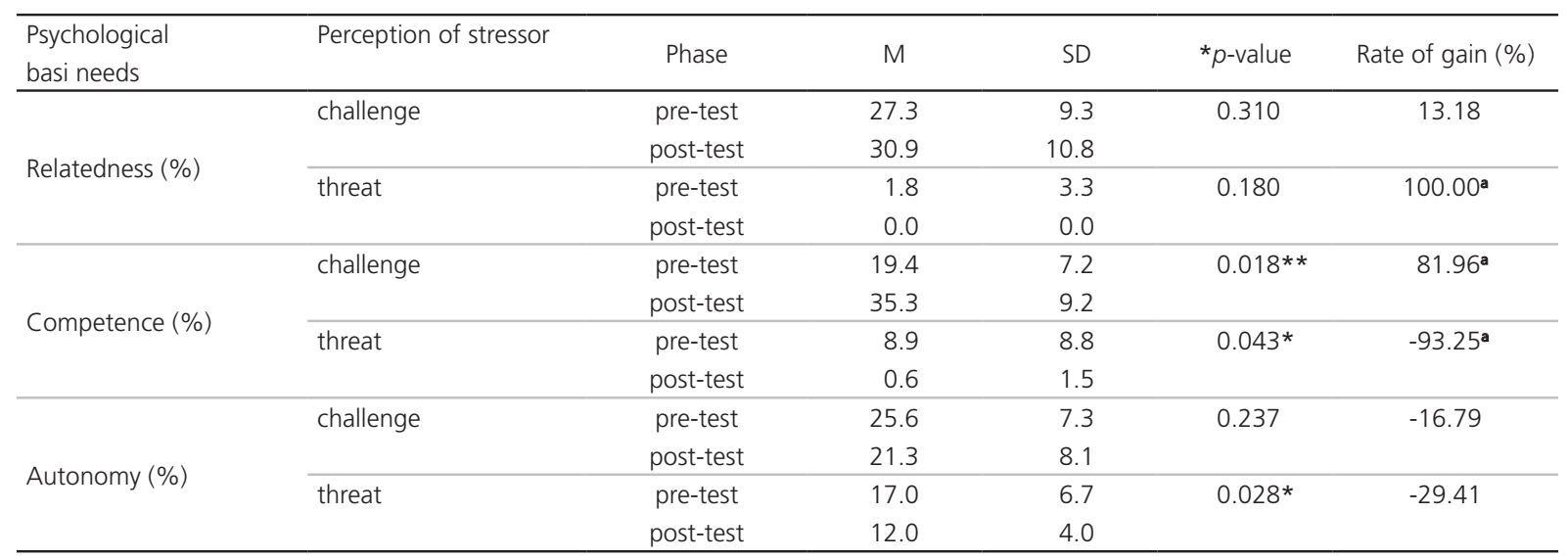

Note: ${ }^{*} p \leq 0.05 ;{ }^{*} p \leq 0.01$, Wilcoxon test; ${ }^{a}$ Clinically significant: $\geq 30 \%$ in the post-test.

\section{Discussion}

This study examined the effects of a psychological intervention focused on coping with pain in children with SCD, based on the principles of the Motivational Theory of Coping (Skinner \& Zimmer-Gembeck, 2007, 2016), using playful activities. Tasks appropriate to the context of these children were developed aiming at promoting the child's pain control and the reduction of suffering, especially in relation to the negative aspects of stressful situations and isolation and helplessness due to the perception of the lack of control of the stressor.

The focus of the intervention, and specifically the JEDOR, was to simulate situations related to the disease, the pain, and everyday experiences considered sources of stress, anxiety, and fear. The activities proposed in the JEDOR enabled the identification and analysis of the children's reactions to these situations and the suggestion of cognitive and behavioral strategies to control their emotions and actions (Anie, 2005; Lima et al., 2014; Motta \& Enumo, 2010). It is a way to promote the acquisition and engagement in behaviors or improvement of the effective ways of coping to relieve the main symptom of SCD - the pain.

The analysis of the intragroup data showed statistically and clinically significant increase in the frequency of the facilitating behaviors to coping with pain, such as "taking medicine", "praying", "resting", "thinking about miracles", "watching TV", "talking to the doctor", "playing", and "talking". Therefore, there was an increase in children's behavioral repertoire of pain control, indicating better coping with the disease, adherence to treatment, and life quality (Anie, 2005) since a larger repertoire of adaptive ways of coping increases the child's level of competence leading to successful pain management (Dias et al., 2013).

The PIPCAF may have changed the participant children's ways of coping with pain and the adaptive process since there was an increase in the children's perception of the effectiveness of the problemsolving and emotional regulation. Both are related to the perception of the pain stressor as a challenge to the need of Competence and Autonomy respectively, according to the MTC. Lima et al. (2014) found 
similar data when they compared the Kidcope and AEHcomp as coping measures. These authors reported a higher frequency of emotional regulation and cognitive restructuring in Portuguese children with cancer during the treatment. These ways of coping are more active strategies to manage pain and are associated with better adaptation to the disease and to the use of hospital medical services provided to children with SCD (Anie et al., 2002).

The intervention data indicated a significant decrease in rumination. This way of coping means that the person perceives pain as a stressor that limits his/her autonomy and ability to make decisions more freely (Skinner et al., 2003; Skinner \& ZimmerGembeck, 2016). It includes repetitive negative or anxious thoughts about a stressful episode (ZimmerGembeck \& Skinner, 2011). It is considered a risky way of coping since it may precipitate a state of depression and anxiety, reflecting on the adherence to the treatment and the clinical evolution (Dias et al., 2013; Garioli, 2011; Motta \& Enumo, 2010; Skinner \& Zimmer-Gembeck, 2016).

The results also showed a clinically significant decrease in the following ways of coping - "social withdrawal" and "avoidance", which are related to threat perception to the need of Relatedness. The same occurred to helplessness that is related to the threat to the need of Competence. These results also suggest a possible positive influence of the PIPCAF on the coping with pain in these children due to the reduction of strategies related to a more passive coping (passive adherence) or negative thoughts (affective coping) (Anie et al., 2002). These ways of coping are related to a poor adaptation to the disease, characterized by a greater perception of pain intensity and less management of pain episodes, higher levels of psychological stress (Anie, 2005; Anie et al., 2002), decrease in school and social activities, and greater levels of anxiety and depression (Barakat, Schwartz, Simon, \& Radcliffe, 2007)).

Another resource proposed by the PIPCAF, the use of playful activities as a therapeutic resource, has shown positive results. Motta and Enumo (2010) consider that this game may stimulate creativity and imagination, improve social functioning and interaction with the group due to the possibility of changing the environment. It allows the approach to the everyday reality too, and encourage the expression of emotions and feelings based on the new learned behaviors. It is worth noticing that the activities proposed in the intervention, specifically in the JEDOR, contributed to the increase of the range of behavioral possibilities; therefore, the children perceived to be more able to control their pain effectively. Thus, the intervention promoted the perception of control or the ability to control a stressful situation by planning strategies or emotional control.

For the child, distraction is an important way to relieve stress by redirecting attention and energy to new stimulus that are internal or available in the environment. In a more aversive condition such as the hospital, in a crossover study, Oliveira, Santos, and Linhares (2017) demonstrated the effectiveness of an audiovisual distraction intervention in acute pain relief in hospitalized children undergoing puncture procedures. Possibly, in their natural context, children with SCD can use this resource during the painful crisis for better pain management (Anie, 2005).

Although having some methodological limitations regarding data generalization due to sample size and absence of a comparative group, this study showed important contributions to the promotion of well-being and to the analysis of the specificities in the process of coping with pain in children with SCD. It also contributed to the field of Pediatric Psychology in terms of the mechanisms and processes of evaluation and psychological intervention in contexts of chronic disease. It is hoped that the ways of coping simulated and reflected in a playful context will be transposed into different contexts in the daily life of these children, improving their feeling of competence in effectively managing the stressors that are as challenging to infant development as chronic pain.

\section{Contributors}

All authors made substantial contributions to the conception, design, writing, and revision and approval of the final version of this manuscript. 


\section{References}

Anie, K. A. (2005). Psychological complications in sickle cell disease. British Journal of Hematology, 129(6), 723-729. https://doi.org/10.1111/j.1365-2141.2005.05500.x

Anie, K. A., Steptoe, A., Dick, M., \& Smalling, B. M. (2002). Coping and health service utilization in a UK study of pediatric sickle cell pain. Archives of Disease in Childhood, 86(5), 325-329. https://doi.org/10.1136/ adc.86.5.325

Armstead, V. E., \& D'Souza, G. (2011). Sickle cell pain. In B. C. McClain \& S. Santhanam (Eds.), Handbook of pediatric chronic pain (pp.177-191). New York: Springer.

Barakat, L. P., Schwartz, L. A., Simon, K., \& Radcliffe, J. (2007). Negative thinking as a coping strategy mediator of pain and internalizing symptoms in adolescents with sickle cell disease. Journal of Behavioral Medicine, 30(3), 199-208. https://doi.org/10.1007/s10865-007-9103-x

Batista, T. F., Camargo C. L., \& Moraes, A. C. (2011). O cotidiano de adolescentes com (vivendo) com anemia falciforme. Boletim do Instituto de Saúde, 13(2), 114-124. Recuperado em junho 20, 2013, de http:// periodicos.ses.sp.bvs.br/pdf/bis/v13n2/v13n2a03.pdf

Brasil. Ministério da Saúde. (2013). Doença falciforme: condutas básicas para tratamento. Brasília: Autor.

Carnier, L. E., Padovani, F. H. P., Perosa, G. B., \& Rodrigues, O. M. P. R. (2015). Estratégias de enfrentamento em crianças em situação pré-cirúrgica: relação com idade, sexo, experiência com cirurgia e estresse. Estudos de Psicologia (Campinas), 32(2), 319-330. https://doi. org/10.1590/0103-166X2015000200015

Chen, E., Cole, S. W., \& Kato, P. M. (2004). Review of empirically supported psychosocial interventions for pain and adherence outcomes in sickle cell disease. Journal of Pediatric Psychology, 29(3), 197-209. https:// doi.org/10.1093/jpepsy/jsh021

Compas, B. E., Jaser, S. S., Dunn, M. J., \& Rodriguez, E. M. (2012). Coping with chronic illness in childhood and adolescence. Annual Reviews Clinical Psychology, 27(8), 455-480. https://doi.org/10.1146/annurevclinpsy-032511-143108

Del Prette, Z. A. P., \& Del Prette, A. D. (2011). Psicologia das habilidades sociais na infância: teoria e prática. São Paulo: Vozes.

Dias, T. L., Oliveira, C. G. T., Enumo, S. R. F., \& Paula, K. M. P. (2013). A dor no cotidiano de cuidadores e crianças com anemia falciforme. Revista Psicologia USP, 24(3), 391-411. https://doi.org/10.1590/S010365642013000300003

Friedberg, R. D., \& McClure, J. M. (2008). A prática da Terapia Cognitiva Comportamental com crianças e
Garioli, D. S. (2011). O impacto da dor nas funções executivas e sua relação com as estratégias de enfrentamento em crianças com Anemia Falciforme (Dissertação de mestrado não-publicada). Universidade Federal do Espírito Santo, Vitória.

Hicks, C. L., von Baeyer, C. L., Spafford, P., van Korlaar, I., \& Goodenough, B. (2001). The Faces Pain ScaleRevised: Toward a common metric in pediatric pain measurement. Pain, 93, 173-183. https://doi. org/10.1016/S0304-3959(01)00314-1

Hostert, P. C. C., Motta, A. B., \& Enumo, S. R. F. (2015). Coping da hospitalização em crianças com câncer: a importância da classe hospitalar. Estudos de Psicologia (Campinas), 32(4), 627-639. https://doi. org/10.1590/0103-166X2015000400006

Lima, A. S., Barros, L., \& Enumo, S. R. F. (2014). Enfrentamento em crianças portuguesas hospitalizadas por câncer: comparação de dois instrumentos de avaliação. Estudos de Psicologia (Campinas), 31(4), 559-571. https://doi.org/10.1590/70103166X2014000400010

McGlinchey, J. B., Atkins, D. C., \& Jacobson, N. S. (2002). Clinical significance methods: Which one to use and how useful are they? Behavior Therapy, 33(4), 529-550. https://doi.org/10.1016/S00057894(02)80015-6

Menezes, A. S. O. P., Len, C. A., Hilário, M. O., Terreri, M. T. R. A, \& Braga, J. A. P. (2013). Qualidade de vida em portadores de doença falciforme. Revista Paulista de Pediatria, 31(1), 24-29. https://doi.org/10.1590/ S0103-05822013000100005

Miranda, F. P., \& Brito, M. B. (2016). Assistência multidisciplinar ao paciente com anemia falciforme na internação de crises álgicas. Uma revisão integrativa. Revista Enfermagem Contemporânea, 5(1), 143-150. https://doi.org/10.17267/2317-3378rec.v5i1.830

Motta, A. B., \& Enumo, S. R. F. (2010). Intervenção psicológica lúdica para o enfrentamento da hospitalização em crianças com câncer. Psicologia: Teoria e Pesquisa, 26(3), 445-454. https://doi. org/10.1590/S0102-37722010000300007

Motta, A. B., Perosa, G. B., Barros, L., Silveira, K. A, Lima, A. S. S., Carnier, L. E., ... Caprini, F. R. (2015). Comportamentos de coping no contexto da hospitalização infantil. Estudos de Psicologia (Campinas), 32(2), 331-341. https://doi. org/10.1590/0103-166X2015000200016

Moura, F. M., Costa Junior, A. L., Dantas, M. S. A., Araújo, G. C. B., \& Collet, N. (2014). Intervenção lúdica a crianças com doença crônica: promovendo o enfrentamento. Revista Gaúcha de Enfermagem, 35(2), 86-92 https://doi.org/10.1590/19831447.2014.02.41822 
Mussa, C., \& Malerbi, F. E. K. (2008). O impacto da atividade lúdica sobre o bem-estar de crianças hospitalizadas. Psicologia Teoria e Prática, 10(2), 83-93.

Oliveira, N. C. A. C., Santos, J. L. F., \& Linhares, M. B. M. (2017). Audiovisual distraction for pain relief in paediatric inpatients: A crossover study. European Journal Pain, 21(1), 178-187. https://doi.org/10.1002/ ejp.915

Poveda, C. L. E. C., Silva, J. A., Passareli, P., Santos, J., \& Linhares, M. B. M. (n.d.). Download PDF containing FPS-R instructions (in French, English and 45 other languages). Retrieved May 29, 2017, from https:// www.iasp-pain.org/files/Content/ContentFolders/ Resources2/FPSR/facepainscale_portugese_brazil_porbr.pdf

Ramos, F. P., Enumo, S. R. F., \& Paula, K. M. P. (2015). Motivational Theory of Coping: A developmental proposal for the analysis of coping with stress. Estudos de Psicologia (Campinas), 32(2), 269-279. https://doi. org/10.1590/0103-166X2015000200011

Sabino, M. F., \& Gradella, D. B. T. (2016). Perfil epidemiológico de pacientes internados por doença falciforme no estado do Espírito Santo, Brasil (20012010). Revista Brasileira de Pesquisa em Saúde, 18(2), 35-41. https://doi.org/10.21722/rbps.v18i2.15082

Silva-Pinto, A. C., Ângulo, I. L., Brunetta, D. M., Neves, F. I., Bassi, S. C., Santis, G. C., \& Covas, D. T. (2013). Clinical and hematological effects of hydroxyurea therapy in sickle cell patients: A single-center experience in Brazil. São Paulo Medical Journal, 131(4), 238-243. https://doi.org/10.1590/15163180.2013.1314467

Skinner, E. A., \& Wellborn, J. G. (1994). Coping during childhood and adolescence: A motivacional perspective. In D. L. Feathermann, R. M. Lerner, \& M. Perlmutter (Eds.), Life-span development and behavior (Vol.12, pp. 91-133). Hillsdale: Lawrence Erlbaum Associates.

Skinner, E. A., \& Zimmer-Gembeck, M. J. (2007). The development of coping. Annual Review of Psychology, 58, 119-144. https://doi.org/10.1146/annurev. psych.58.110405.085705

Skinner, E. A., \& Zimmer-Gembeck, M. J. (2016). The development of coping: Stress, neurophysiology, social relationships, and resilience during childhood and adolescence. New York: Springer.

Skinner, E. A., Edge, K., Altman, J., \& Sherwood, H. (2003). Searching for the structure of coping: A review and critique of category systems for classifying ways of coping. Pychological Bulletin, 129(2), 216-269. https://doi.org/10.1037/0033-2909.129.2.216

Vasconcelos, A. G., \& Nascimento, E. (2016). Teoria Motivacional do Coping: um modelo hierárquico e desenvolvimental. Avaliação Psicológica, 15(Esp.), 77-87. Recuperado em janeiro 20, 2017, de http://pepsic.bvsalud.org/scielo. php?script=sci_arttext $\&$ pid $=$ S1677-047120160 00300009\&lng=pt\&tlng=pt

Zimmer-Gembeck, M. J., \& Skinner, E. A. (2011). The development of coping across childhood and adolescence: An integrative review and critique of research. International Journal of Behavioral Development, 35, 1-17. https://doi.org/10.1093/ jpepsy/jsh021

Received: March 14, 2017

Final version: April 5, 2017

Approved: April 12, 2017 
